\title{
Kolaborasi Pemasaran Gula Merah Petani dengan Badan Usaha Milik Desa Desa di Rumbai Jaya Indragiri Hilir
}

\author{
Muammar Alkadafi ${ }^{1}$, Muh. Said HM ${ }^{2}$, Muhammad April ${ }^{3}$, Fitria Ramadhani Agusti NST ${ }^{4}$ \\ 1,2,3,4 Universitas Islam Negeri Sultan Syarif Kasim Riau \\ Email: muamar@uin-suska.ac.id
}

\begin{abstract}
Abstrak
Salah satu potensi ekonomi masyarakat Desa Rumbai Jaya, Kecamatan Kempas, Kabupaten Indragiri Hilir adalah produksi turunan kelapa lokal. Masalahnya ialah produksi yang besar, tetapi tidak mempunyai jangkauan pasar yang lebih luas. Tujuan pengabdian ialah untuk menciptakan kerjasama atau kolaborasi antara petani dengan Badan Usaha Milik Desa (BUMDes) dalam pemasaran produk gula merah. Metode Pengabdian, tim pengabdi melakukan pendampingan dalam bentuk menfasilitasi para petani melemabagakan para petani untuk bekerja sama dengan BUMDes dalam melakukan pemasaran gula merah ke jangkauan pasar yang lebih luas. Hasil pengabdian, terjadinya kerjasama antara petani BUMDes, untuk memasarkan produk gula merah ke jangkauan pasar (market) yang lebih luas. Kerjasama menghasilkan kesepakatan dan komitmen antara pemerintah desa dan BUMDes untuk membentuk usaha unit bisnis pengelolaan turunan kelapa terpadu.
\end{abstract}

Kata Kunci: Pendampingan, Petani, Kolaborasi, Badan Usaha Milik Desa.

\begin{abstract}
One of the economic potentials of the community of Rumbai Jaya Village, Kempas District, Indragiri Hilir Regency is the production of local coconut derivatives. The problem is large production, but it does not have a wider market reach. The purpose of service is to create cooperation or collaboration between farmers and village-owned enterprises in marketing brown sugar products. Service Method, the service team provides assistance in the form of facilitating farmers to institutionalize farmers to work together with the Village-Owned Enterprises in marketing brown sugar to a wider market reach. The result of dedication is the collaboration between the farmers of Village Owned Enterprises, to market brown sugar products to a wider market reach. The collaboration resulted in an agreement and commitment between the village government and the Village Owned Enterprises, to form an integrated business unit for managing coconut derivatives.
\end{abstract}

Keywords: Assistance, Farmers, Collaboration, Village-Owned Enterprises.

\section{Pendahuluan}

Aktivitas produksi masyarakat Desa Rumbai Jaya ialah sektor perkebunan kelapa lokal, perkebunan pinang dan perkebunan kelapa sawit. Kelapa lokal selama ini diproduksi masyarakat dalam bentuk bahan mentah, dijual kepada penampung (tokeh) yang ada di desa dalam bentuk jenis kelapa bulat, kelapa basah dan dalam bentuk kopra. Selanjutnya, para penampung (tokeh) menjual ke perusahaan (PT. Sambu Group) maupun anak perusahaan Sambu Group. Desa Rumbai Jaya, pada saat ini merupakan sentral produksi gula merah yang diproduksi dari bahan turunan kelapa lokal jenis 
hibrida, produksinya dilakukan secara tradisional oleh masyarakat dalam 10 (sepuluh) tahun terakhir. Pembuatan gula merah dari rendemin nira kelapa hibrida, merupakan alternatif kegiatan usaha masyarakat dalam mengatasi ketidakpastian harga kelapa, karena harga kelapa dan kopra tidak dapat diharapkan sebagai penopang utama biaya kebutuhan ekonomi keluarga.

Produksi gula merah oleh para petani yang berjumlah 30 (tiga puluh) rumah tangga, mampu memproduksi 300 kg gula merah per hari, sedangkan kemampuan penjualan dalam satu hari rata-rata hanya $150 \mathrm{~kg}$ atau (50\%), melalui pembelian oleh para pengepul (agen). Hasil observasi lapangan yang menjadi kendala utama untuk meningkatkan penjualan dan menambah nilai ekonomi produksi petani gula merah ialah terkait jangkaun pasar yang lebih luas, dan hal ini terkait dengan pemasaran. Senada dengan pernyataan Direktur Badan Usaha Milik Desa (Mulyono) menyebut bahwa kendala pemasaran produk gula merah ialah terkait dengan jangkauan pasar, dimana produksi gula merah para petani di desa ini hanya dibeli oleh para agen (tengkulak/pengepul) yang datang membeli ke desa ini. Lanjut Mulyono, menyebutkan pasar produk gula merah ini sebagai produk lokal asli desa Rumbai Jaya belum mampu menembus pasar-pasar modern, karena terkendala dari sisi kualitas produk. Contohnya produk gula merah ini belum bersertifikat dari lembaga yang mempunyai otoritas seperti Sertifikat Produksi Pangan Industri Rumah Tangga (SPP-IRT) dari dinas kesehatan dan sertifikat halal dari LPPOM Majelis Ulama Indonesia. Selama ini, para petani kita belum sadar terhadap hal tersebut, sehingga mereka kurang peduli untuk meningkatkan kualitas produk industri rumah tanggannya. Kemudian disisi lain para petani kita kurang mendapat pengetahuan atau informasi terkait pentingnya kualitas produk dengan adanya jaminan sertifikasi, sehingga produk pertanian gula merah yang dipasarkan lebih terjamin kualitasnya.

Kendala pemasaran produksi gula merah sebagai industri rumah tangga di Desa Rumbai Jaya, strategi pemasarannya dapat dilakukan melalui lembaga ekonomi desa, yaitu Badan Usaha Milik Desa sebagai lembaga yang berfungsi untuk dapat menampung produk-produk unggulan didesa. BUMDes bisa menjadi alternatif saluran pemasaran, dengan meningkatkan perannya sebagai pengumpul dan produsen gula merah dari bahan rendemin nira kelapa hibrida Desa Rumbai Jaya. Melalui saluran pemasaran BUMDes dapat memutus mata rantai tata niaga produk pertanian yang terlalu panjang, BUMDes sebagai agen pemasaran ke jangkauan pasar yang lebih luas, melalui berbagai koneksi/jaringan BUMDes di berbagai daerah lain.

Berangkat dari analisa situasi terkait permasalahan pemasaran produksi gula merah sebagai industri rumahan (home industry) masayarakat petani di Desa Rumbai Jaya dalam upaya meningkatkan hasil penjualan produksinya, maka kami dari tim pengabdi melakukan pengabdian dengan meteode pendampingan dan fasilitasi dalam hal pemasaran produksi gula merah desa Rumbai Jaya. Kegiatan pendampingan difokuskan pada pengembangan produk gula merah dengan metode penyuluhan strategi branding dan pemasaran baik secara manual dan online (e-commerce), 
melakukan kolaborasi antara komunitas petani gula merah dengan BUMDes melalui pemasaran produk. BUMDes melalui jaringan (networking) di berbagai desa di Provinsi Riau sangat efektiv untuk mempercepat pemasaran produk, melalui BUM Des pemasaran produk unggulan desa dapat mempermudah produk gula merah masuk ke pasar-pasar modern di wilayah perkotaan karena BUMDes mempunyai legalitas atau payung hukum dari pemerintah.

Pendampingan sangat penting dilakukan sebagaimana diungkapkan Afandi (2018) dengan konsep pendampingan yang menyebutkan bahwa Pendampingan adalah pekerjaan yang dilakukan oleh fasilitator atau pendamping masyarakat dalam berbagai kegiatan program, karena tugasnya lebih sebagai pendorong, penggerak, katalisator, motivator masyarakat, sementara pelaku dan pengelola kegiatan selanjutnya adalah masyarakat itu sendiri. Pendampingan sebagai suatu strategi dalam upaya meningkatkan mutu dan kualitas dari sumber daya manusia, sehingga mampu mengindentifikasikan dirinya sebagai bagian dari permasalahan yang dialami dan berupaya untuk mencari alternative pemecahan masalah yang dihadapi, kemampuan sumber daya manusia sangat dipengaruhi oleh keberdayaan dirinya sendiri. Oleh karena itu sangat dibutuhkan kegiatan pemberdayaan disetiap kegiatan pendampingan. Pendampingan berarti bantuan dari pihak luar, baik perorangan maupun kelompok untuk menambahkan kesadaran dalam rangka pemenuhan kebutuhan dan pemecahan permasalahan. Pendampingan diupayakan untuk menumbuhkan keberdayaan dan keswadayaan agar masyarakat yang didampingi dapat hidup secara mandiri. Departemen Sosial (2009) menyebut pendampingan adalah suatu proses pemberian kemudahan (fasilitas) yang diberikan pendamping kepada klien dalam mengidentifikasi kebutuhan dan memecahkan masalah serta mendorong tumbuhnya inisiatif dalam proses pengambilan keputusan, sehingga kemandirian klien secara berkelanjutan dapat diwujudkan (Rahmawati \& Kisworo, 2017).

Mubyarto (2004) mengatakan pemberdayaan masyarakat petani adalah upayaupaya yang dilakukan dalam rangka meningkatkan kemampuan masyarakat agribisnis sehingga secara mampu mengembangkan diri dan dalam melakukan usaha secara berkelanjutan. Pemberdayaan diarahkan guna meningkatkan ekonomi masyarakat secara produktif sehingga mampu menghasilkan nilai yang tinggi dan pendapatan yang lebih besar. Upaya peningkatan kemampuan untuk menghasilkan nilai tambah tidak harus ada perbaikan akses terhadap empat hal, yaitu akses sumber daya, akses terhadap teknologi, akses terhadap pasar dan akses terhadap permintaan.

Pendampingan melalui pemasaran produk unggulan gula merah Desa Rumbai Jaya melalui BUMDes dalam strategi pengabdian ini, menjadikan kelembagaan BUMDes sebagai penampung atau membeli produksi gula merah dan melakukan pemasaran ke berbagai daerah, dan berbagai segmen pasar. Dan hal tersebut, sangat bisa dilakukan apabila BUMDes membuat inovasi branding yang menarik bagi konsumen, dan melakukan pemasaran secara online melalui sarana teknologi yang ada pada saat ini. Pemasaran gula merah melalui BUMDes sesuai dengan apa yang dikatakan oleh Keller 
(2008) Pemasaran adalah proses di mana perusahaan untuk menciptakan nilai bagi pelanggannya dan membangun hubungan baik dengan pelanggan serta untuk mengambil nilai lebih dari respon pelanggan sebagai timbal baliknya. Citra mereka sangat penting dalam pemasaran gula merah, lebih lanjut (Kotler, Armstrong, Harris, \& Piercy, 2017) menyebut merek adalah nama, istilah, tanda, simbol atau desain dari produk atau jasa atau kombinasi keseluruhan yang dimaksud untuk mengidentifikasi barang dan jasa dari seseorang atau kelompok penjual dan untuk membedakan dari produk pesaing. Merek juga dapat meninggalkan citra dan pengalaman dibenak konsumen mengenai keuntungan dari produk yang diproduksi dari perusahaan.

Pemasaran gula merah merah melalu internet (e-mareketing) sangat penting dilakukan sebagai disebutkan (Mohammed, Fisher, \& Jaworski, 2003). Pemasaran internet (Internet Marketing) adalah proses membangun dan menjaga hubungan dengan pelanggan melalui aktifitas secara online untuk memfasilitasi pertukaran ide-ide, produk, dan layanan yang dapat memuaskan tujuan dari kedua belah pihak. Pemasaran online memberikan manfaat pada konsumen maupun marketer. Manfaat tersebut memberikan keuntungan bagi konsumen dan marketer (Kotler \& Armstrong, Principles of Marketing, 2010). menyebut keuntungan online marketing untuk konsumen : nyaman, mudah dan pribadi, informasi, interaktif dan langsung.

Strategi pemasaran produk gula merah menjadi fokus utama dalam kegiatan pengabdian ini. Permasalahan utama dalam pengembangan usaha kecil mikro (UKM) dan Badan Usaha Milik Desa (BUMDes) menurut (Djaelani, Asyari, Yuliani, \& Suryadi, 2020) adalah berkaitan dengan pemodalan, manajemen usaha, pengelolaan keuangan dan pemasaran produk yang dihasilkan. Sebagian besar UKM dan BUMDes terutama skala usaha mikro pada industri rumahan (home industry) masih mengalami masalah dalam memperoleh dan meningkatkan penjualan secara berkesinambungan karena pemasaran produk yang mengandalkan caracara pemasaran konvensional. Permasalahan pemasaran yang dihadapi oleh para pelaku Industri Rumahan (Home Industry), UMKM, dan pengelola BUMDes dalam memasarkan produknya dapat diuraikan dengan teknik bauran pemasaran (marketing mix) yang umumnya dikenal dengan teori 4P yakni Product, Price, Place dan Promotion. Dalam teknik pemasaran mengunakan marketing mix ini, beberapa kendala pemasaran dapat dipecahkan secara sederhana oleh para pelaku Industri Rumahan (home industry) Gula Merah dan pengelola BUMDES lancang Kuning Desa Rumbai Jaya.

Tujuan utama kegiatan pengabdian masyarakat ini ialah terciptanya kolaborasi antara para petani dengan BUMDes dalam pemasaran produk gula merah dan pemasaran produk gula merah di desa rumbai jaya dapat menjangkau pasar yang lebih luas, untuk meningkatkan hasil penjualan para petani sebagai pelaku industri rumahan (home industry) gula merah. 


\section{Metode}

Kegiatan pengabdian kepda masyarakat ini diikuti oleh para petani yang memproduksi gula merah, pengelola Badan Usaha Milik Desa Lancang Kuning Desa Rumbai Jaya dan aparat desa Rumbai Jaya. Lokasi pengabdian di Desa Rumbai Jaya, waktu pelaksanaan September-November 2019. Adapun strategi pelaksanaan pengbdian yang dilakukan tim pengabdi untuk menciptkan koloborasi antara para petani dengan badan usaha milik desa untuk melakukan pemasaran gula merah ke jangkau pasar yang lebih luas ialah

1. Tim pengabdi melakukan Focus Groaup Discussion (FGD) dengan para petani yang berjumlah 30 orang dengan para pengelola BUMDes dan aparat desa.

2. Tim pengabdi melakukan pelatihan kepada para petani tentang teknik bauran pemasaran (marketing mix) yakni Product, Price, Place dan Promotion.

3. Tim pengabdi memfasilitasi pembentukan Unit Usaha Perdagangan Gula Merah pada BUMDes Lancang Kuning, dan bersama-bersama mendesain cara pemasaran produksi gula merah ke berbagai daerah, dan ke pasar-pasar modern.

4. Tim pengabdi memfasilitasi, perubahan kemasan produksi gula merah yang lebih modern.

5. Tim pengabdi, memfasilitasi pembuatan website BUM Des dan akun media online untuk pemasaran produk gula merah.

\section{Hasil dan Pembahasan}

\section{Kolaborasi Kelompok Tani dan BUMDes dalam Pemasaran Gula Merah}

Jumlah keluarga pelaku industri rumahan (home industry) yang memproduksi gula merah di Desa Rumbai Jaya sebanyak 30 rumah tangga. Kegiatan pendampingan yang dilakukan tim pengabdi dalam bentuk pendampingan kepada kelompok tani dan pengelolaa BUMDes ialah memfasilitasi terciptanya kolaborasi dalam pemasaran gula merah. Peran BUMDes dalam melakukan pembinaan terhadap para petani dalam memulai usahanya dan mengembangkan usaha gula merah, mendapat bantuan pinjaman permodalan dari kelembagaan BUMDes.

Tabel 1. Jumlah Petani Gula Merah yang Mendapat Bantuan Modal dari BUMDes Lancang Kuning

\begin{tabular}{clc}
\hline No & \multicolumn{1}{c}{ Nama } & Jumlah Pinjaman (Rp) \\
\hline 1 & Rusdi Rahayu & 15.000 .000 \\
2 & Tumiran & 13.000 .000 \\
3 & M. Herlin Efendi & 15.000 .000 \\
4 & Sukamto & 5.000 .000 \\
5 & Abu jamil & 10.000 .000 \\
6 & Asep kurniawan & 10.000 .000 \\
7 & Ujang kuswanto & 20.000 .000 \\
8 & Tugino & 20.000 .000 \\
9 & Jatun Priyo Widodo & 30.000 .000 \\
10 & Areda & 30.000 .000
\end{tabular}




\begin{tabular}{llc}
11 & Samsul Bahri & 15.000 .000 \\
12 & Dasirin & 20.000 .000 \\
13 & Ahmad Solihin & 20.000 .000 \\
14 & Edi Sutrisno & 20.000 .000 \\
15 & Fatimah & 25.000 .000 \\
16 & Herman & 25.000 .000 \\
17 & Sarikun & 30.000 .000 \\
18 & Budiansyah & 30.000 .000 \\
19 & Riko Rantoro & 10.000 .000 \\
20 & Daman & 10.000 .000 \\
21 & Umi Rafikah & 13.000 .000 \\
22 & Rizaliyanto & 10.000 .000 \\
23 & Sukmanah & 5.000 .000 \\
24 & Rohidin & 20.000 .000 \\
25 & Imam Darwini & 4.000 .000 \\
26 & Nasar & 20.000 .000 \\
\hline
\end{tabular}

Sumber: Laporan Keuangan BUM es Lancang Kuning, 2018

Keterbatasan modal yang menjadi salah satu kendala para petani selama ini untuk pengembangan usahanya telah dapat teratasi sejak adanya kelembagaan Badan Usaha Milik Desa Lancang Kuning. BUMDes Lancang Kuning telah berhasil melakukan pemberdayaan untuk peningkatan pendapatan masyarakat yang melakukan usaha, baik dibidang perdagangan, perkebunan, industri kecil yang didanai dari kelembagaan BUMDes. Penelitian (Afiza, 2018), menyebutkan bahwa terjadi peningkatan hasil usaha setelah mendapat pinjaman dari dana BUMDes, sebanyak 76,20\% masyarakat menyatakan usahanya meningkat, kemudian sebanyak 76,20\% masyarakat yang menyatakan pendapatannya meningkat setelah mendapat bantuan dari BUMDes, dan 57\% masyarakat menjawab aset rumah tangga setelah mendapat pinjaman BUMDes menjadi bertambah. BUMDes Lancang Kuning Desa Rumbai Jaya Kecamatan Kempas Kabupaten Indragiri Hilir telah berhasil dalam membantu meningkatkan perekonomian masyarakat Desa Rumbai Jaya melalui pemberian pinjaman dana kepada masyarakat yang menjalankan berbagai bidang usaha seperti perkebunan kelapa sawit, perdagangan (pedagang gorengan dan pedagang pengumpul sawit), industri kecil rumah tangga (pembuatan gula merah) dan jasa (supir pengangkut sawit) sehingga dapat menambah aset rumah tangga selama menggunakan dana BUMDes.

Dalam proses produksi gula merah membutuhkan modal produksi, berupa lahan perkebunan kelapa, tempat pengolahan rendemin nira dan beberap alat produksi lainnya. Para petani yang mendapatkan bantuan dana permodalan awal dari kelembagaan BUMDes. Ini menunjukkan bahwa sinergisitas antara masyarakat petani gula merah dengan BUMDes sudah terjalin sejak awal. Selanjutnya untuk mengembangkan usahanya, keberadaan BUMDes menjadi sangat penting, Menurut Tama (2012) dalam (Nugroho, 2018) BUMDes sepenuhnya dikelola oleh masyarakat desa, sehingga memunculkan konsep dari desa, oleh desa, untuk desa. Adapun cara kerja BUMDes adalah dengan menampung kegiatan-kegiatan ekonomi masyarakat dalam sebuah bentuk kelembagan atau badan usaha. Jadi, dalam pemasaran hasil produksi gula 
merah tersebut, BUMDes menjadi pembeli dan ikut terlibat dalam memasarkan hasil produk industri rumah tangga gula merah. Keterangan direktur BUMDes (Mulyono), bahwa selama ini belum ketemu format atau cara kerjasama antara para petani / pelaku industri rumah tangga terkait pembelian dan pemasaran gula merah oleh BUMDes.

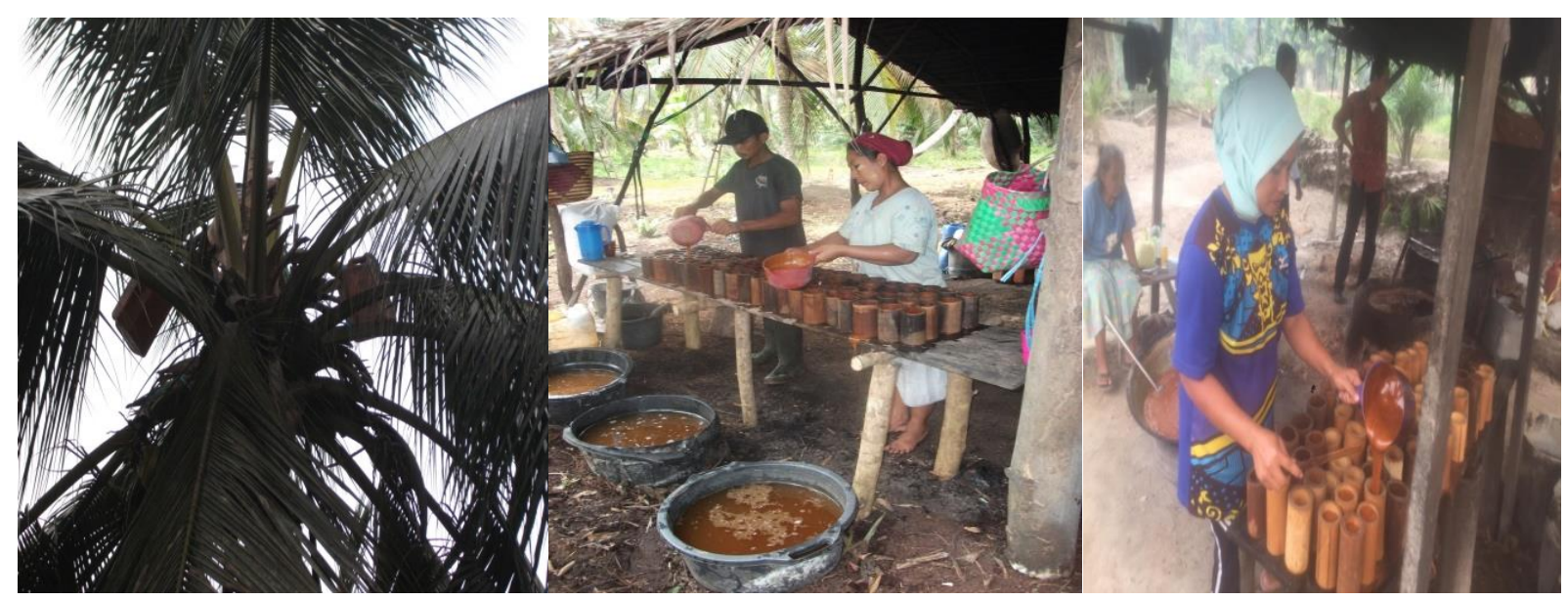

Gambar 1. Proses Produksi Gula Merah

Tim pengabdi melakukan fasilitasi antara kelompok tani dan para pengelola BUMDes, untuk mendiskusikan terkait kerjasama atau kolaborasi antara para petani dengan kelembagaan BUMDes Lancang Kuning. Kolaborasi secara teoritik menurut (Morse and Stephen, 2012), Proses Collaborative Governance dilakukan dengan tahapan yaitu: 1. Assesment (Penilaian) 2. Initiation (Inisiasi) 3. Deliberation (Musyawarah) 4. Implementation (Implementasi). Untuk menciptakan koloborasi antara petani gula merah dengan kelembagaan BUMDes, maka tim pengabdi melakukan kegiatan Focus Group Discussion (FGD), untuk membicarakan kenapa harus dilakukan kerjasama/koloborasi, manfaat dan keuntungan antara petani dan kelembagaan BUMDes, manfaat bagi masyarakat dan pemerintah desa. Focus Group Discussion (FGD) dilakukan tim pengabdi karena melalui FGD, melahirkan konsensus bersama. Hal tersebut sejalan dengan teori tahapan Collaborative Governance dari (Anshell and Gash, 2007), menyebutkan bahwa: (1) Face to face dialogue (dialog/tatap muka), (2) Trust Building (Membangun Kepercayaan), (3) Commitment to Process (Komitmen Bersama), (4) Shared Understanding (Pemahaman Bersama), dan (5) Intermedite outcome ( Pencapaian hasil).
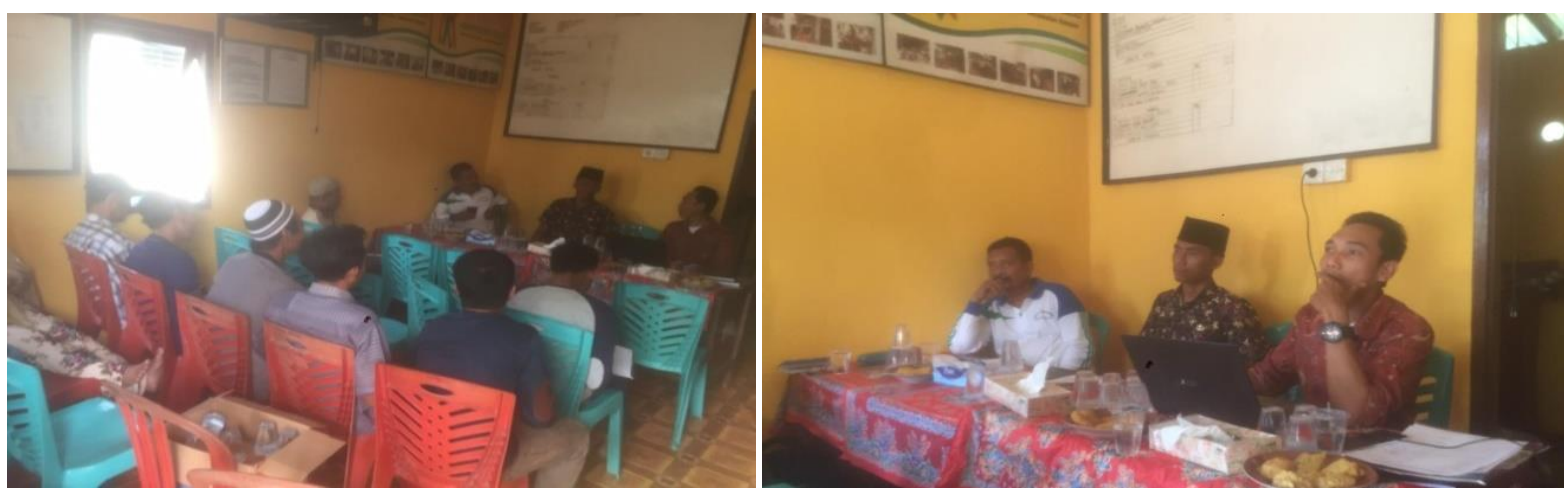

Gambar 2. FGD Kelompok Tani Nngudhi Makmur dan BUMDes Lancang Kuning 
Dari hasil focus group discussion (FGD) yang dilakukan, memunculkan ide dan gagasan bersama untuk melakukan kolaborasi atau kemitraan antara kelompok Tani Ngudhi Makmur dengan pengelola Badan Usaha Milik Desa Rumbai Jaya, sebagai strategi langkah untuk memasarkan produk gula merah ke jangkauan pasar (market) yang lebih luas. Kesepakatan dan komitmen yang terbangun dalam focus group discussion (FGD), ditindak lanjuti oleh pemerintah desa dan pengelolaa BUM Des melalui forum musyawarah desa, menghasilkan kesepakatan membentuk usaha BUM Des berupa unit pengelolaan turunan kelapa terpadu, dan pemerintah desa memutuskan untuk melakukan penyertaan modal APBDes Rumbai Jaya sebesar Rp. 150.000.000,- untuk modal unit pengembangan BUMDes. Langkah awal yang dilakukan BUMDes Lancang Kuning untuk memasarkan produk gula merah kelompok Tani Ngudhi Makmur.

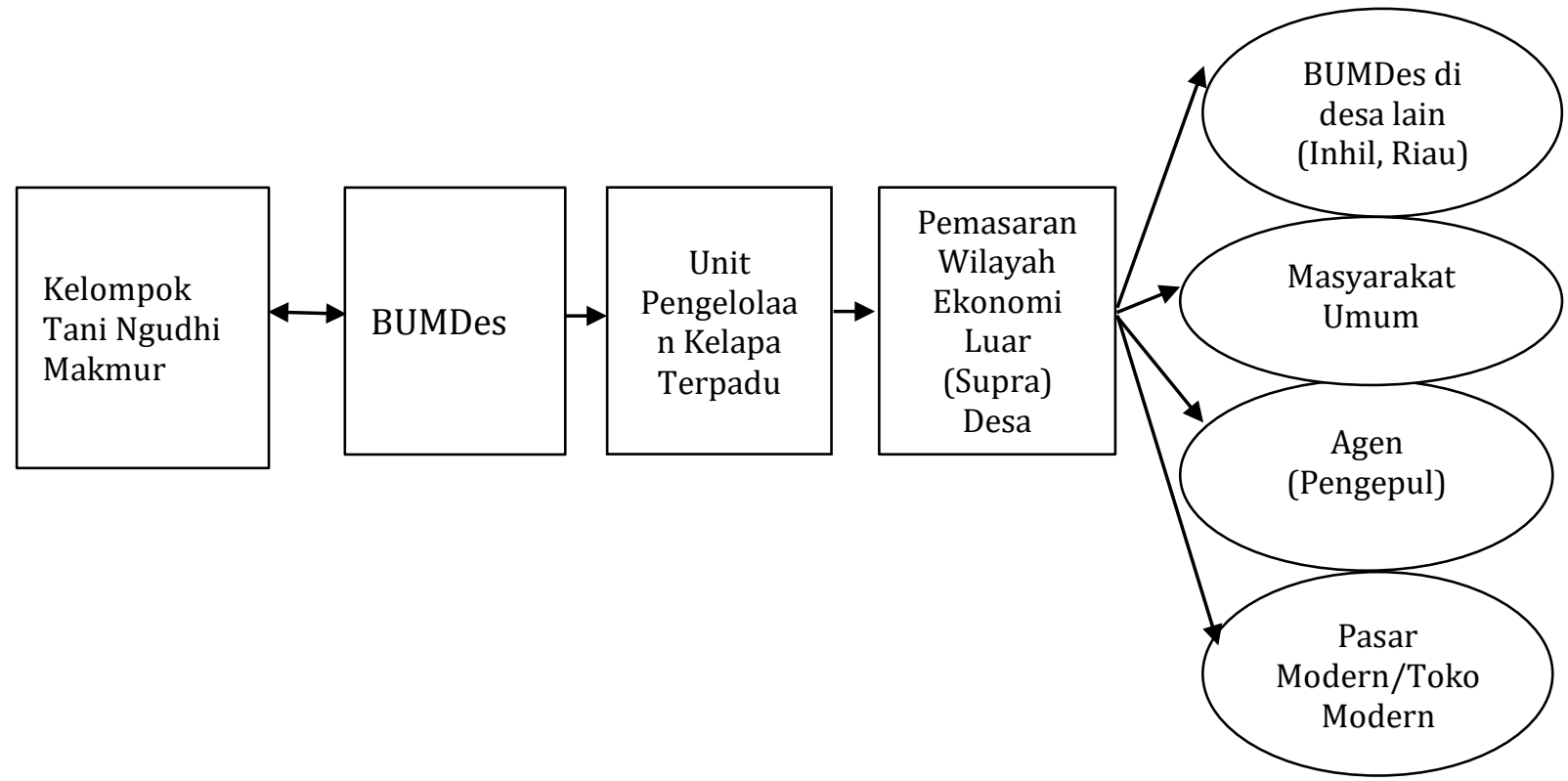

Gambar 3. Koloborasi dan Strategi Pemasaran Gula Merah melalui BUMDes Lancang Kuning Sumber : Data Olahan Tim Pengabdi, 2019

Agar BUMDes dapat bergerak melakukan pemasaran gula merah tersebut, melalui fasilitasi yang tim pengabdi, melakukan pengurusan pembuatan akta notaris unit usaha BUMDes, sebagai syarat untuk mendapat izin industri rumah tangga ( IRT) dari Dinas Kesehatan Kabupaten Indragiri Hilir dan selanjutnya tim pengabdi memfasilitasi pengelola BUM Des untuk mengurus sertifikasi halal dari LPPOM MUI Provinsi Riau. Selanjutnya, setelah izin - izin industri rumah tangga (IRT) dari Dinas Kesehatan dan sertifikasi halal dari LPPOM MUI Provinsi Riau, tim pengabdi memfasilitas untuk membuat kemasan produk gula merah yang menarik dengan mencantumkan izin IRT, dan label halal dari LPPOM MUI, mencatumkan logo BUMDes Lancang Kuning sebagai citra merek bahwa produk gula merah merupakan produksi by BUMDes Lancang Kuning Desa Rumbai Jaya. Dengan demikian, produk gula merah dapat menjadi produk unggulan desa Rumbai Jaya (one village one product). 

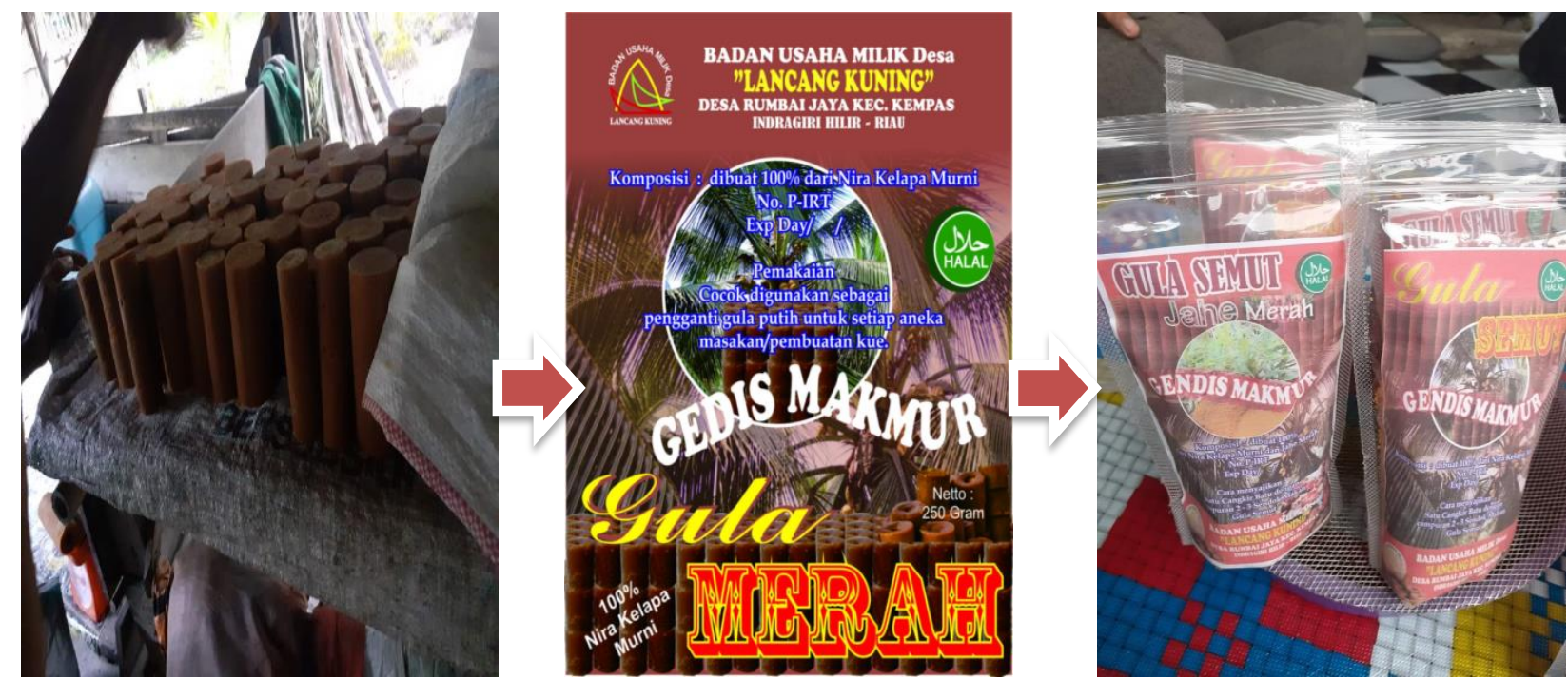

Gambar 4. Perubahan Produksi dan Kemasan Gula Merah

BUMDes, saat ini sudah bergerak untuk melakukan proses pengurusan izin industri rumah tangga (IRT) dari Dinas Kesehatan Kabupaten Indragiri Hilir dan selanjutnya pengurusan sertifikasi kehalalan dari LPPOM MUI Provinsi Riau. Saat ini untuk mempercepat pengenalan produk gula merah desa Rumbai Jaya, pengelola BUMDes Lancang Kuning telah membuat blog https://BUMDeslancangkuningdesarumbaijaya.wordpress.com/ dan akun media sosial untuk mengenalkan dan memasarkan produk gula merah. Proses tahapan pendampingan dan pemberdayaan kelompok tani ngudhi makmur dan pengelola BUMDes Lancang Kunig Desa Rumbai Jaya, menghasilkan inovasi produksi gula merah menjadi gula semut yang dikemas secara lebih modern.

\section{Simpulan}

Hasil kegiatan pengabdian berbasis pendampingan, terjadi perubahan untuk melakukan inovasi proses tahapan produksi gula merah, yang lebih baik dari sebelumnya dari aspek, kebersihan dan kesehatan lingkungan produksi, para petani termotivasi untuk melakukan perubahan bentuk produk gula merah dengan banyak alternatif varian cetakan, agar lebih menarik. para petani akan melakukan perubahan kemasan gula merah yang sederhana, tradisional menjadi lebih berkualitas, lebih modern, mempunyai merek yang memiliki khasan daerah (desa rumbai jaya). hasil pendampingan menciptakan kerjasama atau kolaborasi antara petani dengan Badan Usaha Milik Desa Rumbai Jaya, sebagai strategi langkah untuk memasarkan produk gula merah ke jangkauan pasar (market) yang lebih luas. Kolaborasi menghasilkan kesepakatan dan komitmen pemerintah desa dan pengelolaa BUMDes membentuk usaha BUMDes berupa unit bisnis pengelolaan turunan kelapa terpadu. pengelola BUMDes, sudah bergerak untuk melakukan proses pengurusan akta notaris, izin industri rumah tangga (IRT) dari Dinas Kesehatan, sertifikasi kehalalan produk dari LPPOM MUI Provinsi Riau, membuat kemasan yang lebih menarik, berkualitas dan modern meskipun 
realisasinya masih dalam tahap proses.

Tim pengabdi memberikan saran: Pertama, para petani gula merah yang tergabung dalam kelompok tani Ngudhi Makmur, agar tetap konsisten dan terus melakukan inovasi produksi gula merah agar produk lebih berkualitas dan mudah untuk dipasarkan pada pasar (market) yang lebih luas. Kedua, pengelola Badan Usaha Milik Desa Lancang Kuning untuk segera melakukan pengurusan izin IRT dari Dinas Kesehatan Kabupaten Indragiri Hilir dan selanjutnya mengurus sertifkat kehalalan produk gula merah dari LPPOM MUI Provinsi Riau, agar unit usaha bisnis turunan kelapa terpadu BUMDes yang dibentuk dapat dioperasionalkan untuk memasarkan produk gula merah kelompok Tani Ngudhi Makmur ke Badan Usaha Milik Desa yang ada di Kabupaten Indragiri Hilir dan bahkan BUMDes yang ada Provinsi Riau, dan memasarkan produk gula merah ke toko-toko modern.

\section{Referensi}

Afandi, A. (2018). Participatory Action Research (PAR) Metodologi Alternatif Riset dan Pengabdian Kepada Masyarakat Transformatif. LPPM UIN Sunan Ampel.

Afiza, Y. (2018). PERANAN BADAN USAHA MILIK DESA (BUMDes) LANCANG KUNING DALAM PENINGKATAN EKONOMI MASYARAKAT PENGGUNA DANA BUMDES DESA ....Selodang Mayang, 1-7. Retrieved from https://ojs.selodangmayang.com/index.php/bappeda/article/view/83

Djaelani, S., Asyari, Y., Yuliani, Y., \& Suryadi, H. (2020). Strategi Pemasaran Buah Jeruk Petani Melalui Bumdes Desa Karang Bunga Kecamatan Mandastana. Humanism: Jurnal Pengabdian Masyarakat, 1(2), 81-92. https://doi.org/10.30651/hm.v1i2.5396

Keller, K. . K. (2008). Strategic Brand Management: building, measuring, and managing brand (4th edition). Pearson/Prentice Hall.

Kotler, P., Armstrong, G., Harris, L. C., \& Piercy, N. (2017). Principle of Marketing 7th European edition. Foreign Affairs.

Mubyarto. (2004). MENUJU SISTEM EKONOMI PANCASILA : Jurnal Ekonomi Dan Bisnis Indonesia.

Nugroho M. Rudi. (2018). Penerapan Pola Sinergisitas Antara BUMDes dan UMKM Dalam Menggerakkan Potensi Desa di Kecamatan Saptosari. SEMBADHA: Seminar Hasil Pengabdian Kepada Masyarakat, 28-37.

Rahmawati, E., \& Kisworo, B. (2017). Peran Pendamping dalam Pemberdayaan Masyarakat Miskin melalui Program Keluarga Harapan. Journal of Nonformal Education and Community Empowerment. https://doi.org/10.15294/pls.v1i2.16271 